\title{
Firm-specific determinants of FDI from GCC to MENA countries
}

\author{
Oualid Abidi \\ College of Business Administration, American University of the \\ Middle East \\ Kuwait \\ oualid.abidi@aum.edu.kw
}

Roger Antoun

College of Business Administration, American University of the Middle East

Kuwait

roger.antoun@aum.edu.k.w

Houshang Habibniya

College of Business Administration, American University of the Middle East

houshang.habibniya@aum.edu.k.w

\section{Vladimir Dzenopoljac}

College of Business Administration, American University of the Middle East

Kunvait

vladimir.drenopoljac@aum.edu.kw

Abstract. The paper analyses the firm-level factors that encourage companies from the Gulf countries to conduct investments in the Middle East and North Africa (MENA) using mergers and acquisitions. Numerous local investors do not seem to be deterred by dissuasive locational variables and ineffective integration in the MENA region. Trade agreements amongst MENA countries, e.g., Arab Maghreb Union, Gulf Cooperation Council (GCC), and the Arab Cooperation Council did not enhance foreign direct investment (FDI) between those nations due to structural gaps and incongruences. Therefore, the aim of this research consists in investigating the extent to which GCC firms' decisions to conduct investments in MENA region are explained by their characteristics (size, age, performance, state ownership, and debt structure). Those factors are assumed to exert an influence on M\&A decisions along with other institutional and economic factors. The findings reveal that while firm's size and performance exert a positive effect on a firm's decision to expand within MENA region, state ownership has a negative influence. The study also aligns with the results from more mainstream research
Received:

June, 2018

1st Revision: September, 2018

Accepted: November, 2018

DOI:

$10.14254 / 2071$ $8330.2018 / 11-4 / 1$ 
on born-global firms, since firm's age has no significant power on internal MENA FDI outflows. This study sheds light on a rather underexplored research area. Future research could examine the impact of other explanatory organizational and country-level variables.

Keywords: FDI, GCC, MENA, mergers and acquisitions, firm-specific variables, state-owned enterprises.

JEL Classification: E22, F21, G34

\section{INTRODUCTION}

At present, Arab economies are experiencing important and even critical changes in economic terms. The drop in oil prices has undoubtedly affected the entire region and changed the flow of investments. The GDP growth rate peaked in 2012, reaching 6.6 percent, and then dropping to just an increase of 2 percent in 2014. Imports of goods and services increased while exports of goods and services decreased. As for the unemployment rate, in 2014 it increased to 11.5 percent, which is much higher than the global average unemployment rate for that year, which was 5.6 percent (Dzenopoljac et al., 2017). However, the countries of the Arab region are seen as developing economies. Additionally, these countries have been characterized by expanding trade structures in recent times, with the aim of greater regional integration and participation in the global trading environment, which in turn has the potential to achieve higher levels of growth and national development (Dzenopoljac et al., 2018).

Foreign direct investment (FDI) is one of the most used entry modes for organizations to expand their operations abroad. Financial regulatory systems were reformed in order to enhance capital circulation between the nations in the late 1990's (Cammett, 1999). Developing economies that joined the World Trade Organization became attractive destinations for international investors (Chiemeke, 2012). Their local market potential is a powerful determinant of FDI inflows (Jadhav, 2012; Nunnenkamp, 2002). Improvements of transportation and communication technologies also contributed to increased attractiveness of those nations as potential profit/cost centres for multinationals. Privatization of state-owned enterprises in several MENA countries also promoted FDI flows into their economies (Chiemeke, 2012). This led to substantial growth of FDI net inflows in MENA countries overall. FDI's percentage of GDP exceeded 3\% between 2005 and 2010. This was followed by a sharp decrease below 2\% since 2011 (Abidi, Dzenopoljac and Janošević, 2017). Arab countries, in particular, offered attractive incentives to promote FDI essentially through loosening of various restrictions. For instance, Algeria allowed international companies create joint ventures with the national hydrocarbons provider to exploit local reserves. Libya accepted minority ownership of foreign investors in specific sectors (Sekkat, 2014). Egypt and Morocco were among the top 5 FDI recipients in Africa in 2017 with the total inflows of $\$ 7.4$ bln and 2.7 bln respectively. Despite its advanced ranking, Egypt's FDI inflows registered an $8 \%$ decrease in comparison to the previous year. FDI inflows rose in West Asian Arab countries such as Jordan (7\%), the United Arab Emirates (8\%) and Qatar (27\%). Only Saudi Arabia registered a dramatic 80\% decline due to severe divestments and equity transfers from foreign multinationals to their domestic partners (UNCTAD, 2018).Sekkat (2014) demonstrated that Arab companies investing in other Arab economies are less sensitive than non-Arab investors to locational impediments (inadequacies in human capital, intellectual property protection, infrastructure and openness to trade).

The purpose of this paper is to probe into the role the firm-level characteristics have in explaining FDI decisions among GCC investors in MENA countries. 
Inward FDI in MENA countries was impaired by institutional insufficiencies and local government's influence (Toone, 2012). Research suggests other reasons such as limited openness to trade and credit supply, economic instability, fluctuation of inflation and interest rates as well as oil prices (Aysan, Pang, \& Veganzones-Varoudakis, 2009; Chiemeke, 2012).

Thus, this study would determine firm-specific factors that endorse GCC investors despite the current institutional and economic realities in MENA markets. In this sense, Sekkat (2014) suggests two possible explanations. The first pertains to the ownership structure of investors. In most cases, FDI is supplied by governmental agencies that comply with national interests and aspirations. The second explanation emphasizes the importance of informal networks in Arab countries that allow Arab investors to overcome more easily the information asymmetry at local markets. Therefore, homeland state ownership is seen as a prominent explicative firm-specific variable among others in our model. Government endorsement and international influence can lead to exclusive deals and provide advantageous conditions for investment in uncertain business environments such as MENA countries.

The study of FDI determinants in the MENA region has received relatively less attention from academics (Rogmans \& Ebbers, 2013). Researchers did not reach a consensus regarding the explicative FDI variables that explain FDI inflows in MENA economies (Moosa, 2009). As a result, this work aims to offer better understanding of the determinants behind mergers and acquisitions (M\&A) conducted by GCC companies in MENA countries. The objective is to probe into the role of home country governments in promoting outbound FDIs as part of a broad economic and political vision. Company's scope is also included in the model as state-owned companies are mostly large organizations with long-standing operations in their area of activity.

The paper is organized as follows. The first section outlines the literature review on FDI inflows in MENA countries. Then, the conceptual framework including the research hypotheses and the methodology is presented in the next section. Estimation results and analysis are discussed in the following section. Last, the model results along with the discussion and future research avenues are discussed.

\section{LITERATURE REVIEW}

FDI is defined as "a movement of capital (and other resources) from a parent corporation in the home country that creates a substantial equity interest in a host country corporation, called a subsidiary" (Pugel, 1981: 220). In this sense, host country locational factors, including macroeconomic and institutional indicators, in particular, have been widely discussed as the primary drivers of FDI into MENA economies.

Macroeconomic determinants include the market size, the ratio of government expenditures (Mohamed \& Sidiropoulos, 2010), and the current account of the balance of payments (Van Wyk \& Lal, 2010). Inward FDI in MENA region is positively influenced by the level of GDP (Aysan et al., 2009; Moosa, 2009), and GDP per capita (Helmy, 2013; Rogmans \& Ebbers, 2013).Interest rates on the contrary effect negatively private investment in MENA countries (Aysan et al., 2009).

The review of previous research reveals however controversial results in regards to the effect of natural endowments in MENA countries including oil and gas resources. While one study demonstrated a positive influence (Mohamed \& Sidiropoulos, 2010), others surprisingly suggested the opposite effect (Rogmans \& Ebbers, 2013; Yean, Nee, \& Yi, 2015). The latter refers to what is called the "Dutch Disease". If a country's earnings from the export of natural resources increase, the exchange rates of local currency will be higher. This affects the competitiveness of the local economy as a profitable FDI destination (Rogmans \& Ebbers, 2013).

The influence of institutional FDI determinants in MENA countries was studied from different angles including the level of corruption in public administration (import and export licenses, money exchange, 
taxation, loans, etc.) and the investment conditions including contract enforcement, risk of expropriation and repatriation of profits (Helmy, 2013; Mohamed \& Sidiropoulos, 2010). For instance, Inward FDI in Arab countries is negatively associated with the level of country risk (Moosa, 2009), and political instability (Salem \& Baum, 2016). Openness to trade and business freedom exert a positive influence on FDI in MENA markets (Helmy, 2013; Van Wyk \& Lal, 2010).FDI inflows in MENA economies are also stimulated by (a) higher enrolment in tertiary education among population and investments in research and development, and (b)cheaper labor and technology costs (Moosa, 2009).

Regarding the number of investments exchanged between MENA countries, the share of intra-Arab FDI in rapport with the total Arab FDI outflows decreased after 2003 (Sekkat, 2014). Inter-Arab investments recorded a regression from 370 billion dollars in 2015 to 310 billion in 2016 (Kanady, 2017). The creation of regional trade agreements did not have a significant effect on bilateral investments, though the stated objectives of those deals included economies of scale, growth opportunities and reduction of industrial duplication (Cammett, 1999). The failure of MENA trade agreements might be due to the structural differences that still exist, despite historical, linguistic, cultural and institutional similarities (Rogmans \& Ebbers, 2013). For example, only Egypt, Jordan, Morocco and Tunisia have stated their competition laws, and few countries have dispute resolutions systems (Romagnoli \& Mengoni, 2009).

However, numerous MENA companies were able to invest in other countries in the region despite inconclusive regional integration and discouraging macroeconomic and institutional indicators. Examples are spotted in different sectors including telecommunications, banking, retailing and food. The examination of those cases reveals that the amount of investments is quite impressive, taking into account the degree of political and economic instability in host countries. Here lays the contribution of this manuscript that attempts to advocate firm-level characteristics as potential determinants of the investment decision in MENA markets among GCC companies. Overall, the central assumption posits that company's scope and characteristics offset the unfavourable investment conditions in other MENA economies. This premise could be valid insofar as influential countries in the region are using FDI in their attempt to gain more economic and political power and have new allegiances.

\section{HYPOTHESES DEVELOPMENT}

The study of firm-level FDI factors can provide interesting information about the identity and profile of regional investors in MENA countries. These actors do not seem to be affected by institutional and macroeconomic variables and the limitations of trade agreements. As the amount of work conducted on FDI determinants in the MENA region is almost inexistent, few past studies that focused on inward investments in transition economies can be revealing. For instance, host country risk was found to have no significant effect on western FDI in central and eastern European countries (Bevan \& Estrin, 2004). Institutional and political factors were proved to be less powerful determinants of inward FDI than economic variables in BRICS economies (Jadhav, 2012). Furthermore, political perceived political, exchange rate and inflation risk had no significant effect on inward FDI in Yemen (Al-Jaifi, Abdullah, \& Regupathi, 2016).

Another study examined the determinants of Indian and Chinese acquisitions provides insightful facts for this research. It was found that the likelihood of Chinese and Indian acquisitions in the mining industry is higher when locational determinants are deficient. Besides, the negative effect of deficient rule of law, regulatory quality, control of corruption and political stability decreases when the amount of the deal and the profitability of the target company increase (De Beule \& Duanmu, 2012). Interestingly, most of MENA companies expanding within their region are deep-seated in local economies and represent major employers. The close ties between MENA governments and the tacit alliances that are taking place can contribute to 
the general understanding of FDI motives of local investors. A set of hypotheses is tested accordingly in this manuscript to account for the role of state affiliation along with other firm-level variables.

First of all, firm age is assumed to be a decisive variable explaining GCC companies' growth in the MENA region. This is in line with the premises of old paradigm that stipulates that the development of distinctive capabilities is a prerequisite to FDI Decision (Dunning, 1977, 2000). Firms conduct FDI once they develop specific advantages. The global expansion would allow then the exploitation of those advantages in foreign markets to outperform local competition (Hymer, 1960; Acs, Morck, Shaver \& Yeung, 1997). Ownership-specific advantages that encourage FDI include technological development, marketing and advertising, managerial and organizational capabilities, and capital cost-advantages (Pugel, 1981).

Results from the literature show that the probability of achieving outward FDI is higher for Indian companies with longer business and production experience (Pradhan, 2004). In addition, the pursuit of internationalization among American Internet firms is largely dependent on the accumulation of a robust reputation (S. Kotha, Rindova, \& Rothaermel, 2001). Older firms are likely to develop more innovative outputs than their younger counterparts (R. Kotha, Zheng, \& George, 2011; Withers, Drnevich, \& Marino, 2011).

Overall, the assertion of this paper is that more experienced companies would be more confident in dealing with uncertain environments such as those in several MENA markets as they can count on their cumulated managerial capabilities. Gradual engagement of firms in international marketplace help overcoming information asymmetry in new markets. The Uppsala school evolutionary model proposed by Johanson \& Vahlne (1977) assumes that knowledge about local markets, cultures, and practices is a key condition for the pursuit of internationalization. Prior knowledge accumulation through exports reduces risk and uncertainty and facilitates the engagement of more aggressive entry modes.

Hypothesis 1: A GCC firm's decision to achieve an acquisition in the MENA region is positively affected by its age

Other firm-level factors are likely to explain FDI decision in MENA economies, such as firm size. The latter has a positive effect on Japanese horizontal FDI outflows. Larger firms may afford more easily the scale-independent initial costs of FDI (Todo, 2011). The same findings were obtained in a study conducted on Indian companies operating in pharmaceutical and metals and metal products industries. Firm sales had a significant impact on outward FDI committed by those firms (Mehta, 2016).

Hypothesis 2: A GCC firm's decision to achieve an acquisition in the MEN A region is positively affected by its size

Credit constraints, as measured by a debt-to-asset ratio, limit foreign investments of Japanese firms, since it affects their ability to finance the fixed initial costs of FDI necessary for effective information collection and networking in foreign markets (Todo, 2011). In the same sense, the financial situation of funding bank has a positive influence on the predisposition of Japanese firms to invest in the United States. Any decrease in the credit rating of the investor's main bank turns news plants a less desirable option than joint ventures or other types of FDI (e.g. plant expansion, increase in equity stakes). This result can be due to the strong bonds between Japanese companies and their main banks (P. Wang, Alba, \& Park, 2013).

Hypothesis 3: A GCC firm's decision to achieve an acquisition in the MENA region is positively affected by its leverage

Hyun \& Hur (2013) demonstrated that South-Korean firms achieving high productivity rates are more likely to invest in countries characterized by tougher conditions for investment. Similar results were obtained by Todo (2011) who studied Japanese firms. Although minor, productivity had a positive impact on their FDI decision (Todo, 2011). The productivity of Indian manufacturing firms is also a significant determinant of their outward FDI(Thomas \& Narayanan, 2017).

FDI decision is positively influenced by financial performance indicators, namely the net turnover to networking capital, equity multiplier, and net profitability (Palade, 2016). 
Hypothesis 4: A GCC firm's decision to achieve an acquisition in the MENA region is positively affected by its performance

The last dimension deemed relevant in explaining regional expansion through investment in MENA markets deals with ownership structure. Several studies have stressed the positive effect of state-ownership on firm's ability to moderate investment impediments in challenging business environments. Malaysian companies linked with the government are prominent suppliers of outward FDI especially in the energy sector and financial services (Yean et al., 2015). Government support is a determinant of outward Chinese FDI as well (C. Wang, Hong, Kafouros, \& Boateng, 2012). Other results show that home country government support and well-developed host country institutions reduce the need for cumulated experiential knowledge and capabilities about the host market and increase the likelihood of FDI decision for Chinese firms (Lu, Liu, Wright, \& Filatotchev, 2014).

State ownership attenuates Chinese multinationals' exposure to expropriation risks when investing abroad. Strong home-host political relations attenuate Chinese multinationals' aversion to expropriation risks. This positive moderating effect is higher for State-Owned Enterprises (SOEs). Chinese SOEs are less averse to expropriation risks in host countries highly dependent on exporting to the Chinese market (Duanmu, 2014).

Hypothesis 5: A GCC firm's decision to achieve an acquisition in the MENA region is positively affected by the percentage of state ownership

\section{METHODOLOGY}

In this section, we will first present the database that we built. Then, we will discuss the model and its estimation technique. Finally, we will provide a detailed description of all the variables used in our model.

\subsection{Data}

In our study, we focus on outward FDI decisions by publicly-listed companies in the Gulf Cooperation Council (GCC) countries, namely Bahrain, Kuwait, Oman, Qatar, Saudi Arabia and the United Arab Emirates within the MENA region in the period 2008-2016. We automatically generated the data from the Thomson Reuters Eikon database for a total of 613 observations covering all industries.

\subsection{The estimated model}

Our dependent variable, the outward FDI decision, is a dummy variable taking the value of 1 if a GCC firm undertook a merger and acquisition (M\&A) operation in a MENA country during the 2008-2016 period and zero otherwise. The literature states that mergers and acquisitions represent one of the forms of FDI that include other types: joint venture, new plant, and others, e.g. plant expansion, increase in equity stakes (P. Wang et al., 2013). Since our dependent variable is dichotomous, the most appropriate estimation technique is a logistic regression. Thus, our estimated model is written in the following fashion:

$$
\text { Acquiring decision }=\beta_{0}+\beta_{1} \text { age }_{i}+\beta_{2} \text { size }_{i}+\beta_{3} \operatorname{perf}_{i}+\beta_{4} \text { debt }_{i}+\beta_{5} \text { own }_{i}+\varepsilon_{i}
$$

Where:

- $\quad a g e_{i}$ is thenumber of active years for GCC firm $i$ at the time of the transaction if any.

- $\quad$ size $_{i}$ is the size of GCC firm $i$ measured by the natural logarithm of its total assets in US dollars at the time of the transaction if any. 
- $\quad \operatorname{perf}_{i}$ is the financial performance of GCC firm $i$ measured by the average return- on-equity ratio (ROE) for the three years preceding the outward M\&A decision. For companies that did not invest in the MENA region in the selected period, the average ROE for the last three years of activity was registered.

- $\quad d e b t_{i}$ is the measure of leverage of GCC firm $i$ measured by the debt-to-equity ratio (D/E) for the three years preceding the outward M\&A decision. For companies that did not invest in the MENA region in the selected period, the average $\mathrm{D} / \mathrm{E}$ for the last three years of activity was registered.

- $\quad o w n_{i}$ is the percentage of home-country government and sovereign fund share in the capital structure of the outward-investing GCC firmi.

The number of active years is expected to have a positive impact on the outward investment decision. As for the size of the company, the empirical evidence shows it has a positive effect on the investment decision among GCC firms in the MENA region. Likewise, state ownership, performance, and leverage are expected to encourage intra-MENA M\&A.

Table 1

Sample Summary Statistics

\begin{tabular}{|c|c|c|c|c|c|}
\hline \multicolumn{6}{|c|}{ Summary statistics for investing GCC firms } \\
\hline Variable & Obs. & Mean & St. Dev. & Min & Max \\
\hline Total Assets & 136 & 19.931 & 2.701 & 13.749 & 26.813 \\
\hline Performance & 136 & 0.027 & 0.605 & -12.080 & 1.440 \\
\hline Leverage & 136 & 0.732 & 2.026 & -20.360 & 12.54 \\
\hline Government Ownership & 136 & 0.080 & 0.163 & 0 & 0.81 \\
\hline Active Years & 136 & 26.568 & 13.159 & 1 & 63 \\
\hline \multicolumn{6}{|c|}{ Summary statistics for non-investing GCC firms } \\
\hline Variables & Obs. & Mean & St. Dev. & Min & $\operatorname{Max}$ \\
\hline Total Assets & 477 & 21.528 & 2.318 & 13.754 & 27.012 \\
\hline Performance & 477 & 0.137 & 0.101 & -0.220 & 0.470 \\
\hline Leverage & 477 & 0.696 & 1.217 & -2.590 & 9.650 \\
\hline Government Ownership & 477 & 0.088 & 0.176 & 0 & 0.84 \\
\hline Active Years & 477 & 25.787 & 15.058 & 0 & 62 \\
\hline
\end{tabular}

Note: Natural logs are taken for total assets

\section{EMPIRICAL RESULTS AND ANALYSIS}

\subsection{Summary statistics}

Our analysis starts with a presentation of our sample's summary statistics. Table 1 showcases the mean, standard deviation, minimum and maximum values of the variables used in our empirical model by distinguishing between investing and non-investing GCC firms. A total of 613 observations were used to run the model. Out of this number, 136 observations represent M\&A decisions made by 86 companies between 2008 and 2016 whereas 477 publicly-listed companies in the GCC countries did not undertake any M\&A transaction within the MENA region. 


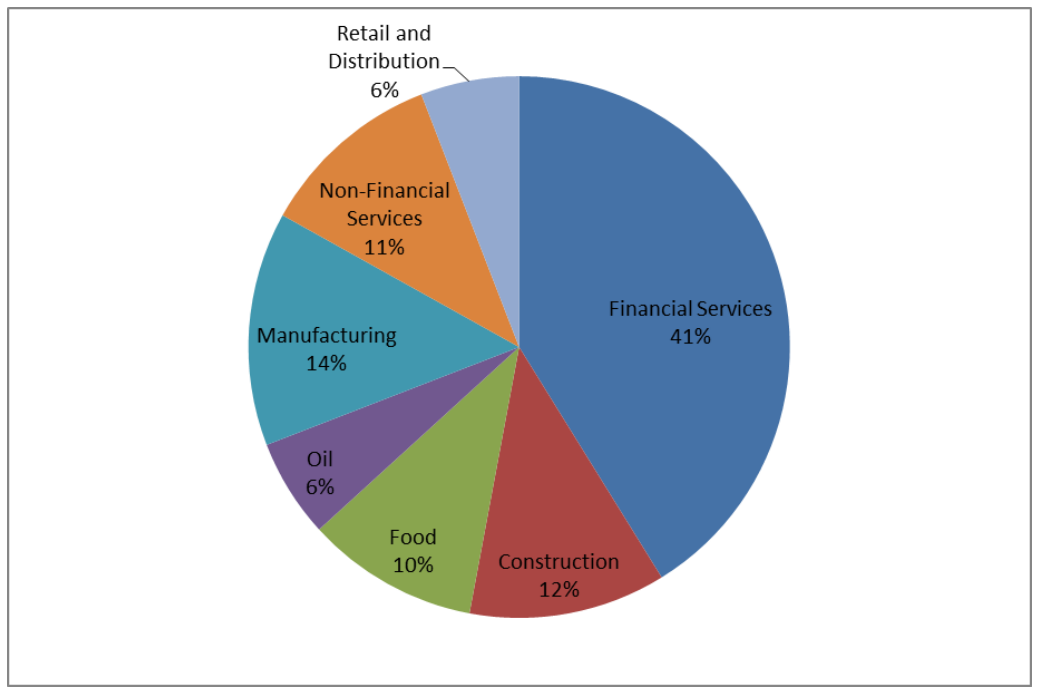

Figure 1. Sectoral outward FDI within the MENA region between 2008 and 2016

Looking at Table 1 figures, we notice that, in our sample, companies that engaged in M\&A activities within the MENA region performed better than non-investing companies on average $(13.7 \%$ and $2.7 \%$ respectively). Standard deviation values for performance and leverage are quite high. This can be explained by the fact that the observed companies stem from different industries. Differences in average total assets, leverage, ownership and active years are small. Figure 1 showcases a sectoral breakdown of GCC-firm M\&A transactions within the MENA region between 2008 and 2016. It is clear that the financial sector was the most active in terms of outward investments. Table A1 in Appendix A describes the number of M\&A transactions per country between 2008 and 2016.

\subsection{Empirical results}

The logistic regression results are given in Table 3. Model 1 showcases the original results of the regression whereas Model 2 provides the odds ratios that were privileged in our analysis below. Other goodness-of-fit measures are given in Table A2 of Appendix A.

First, our study shows that the size of companies has a positive and significant effect on the probability of outward FDI within the MENA region. This result is in line with the empirical literature (Mehta, 2016; Todo, 2011) and supports Hypothesis 2. Company's scope is a decisive factor for investments in MENA region. Host countries in the region are probably offering more convincing guarantees for large GCC investors to access and gain grounds in local markets and overcome impediments that other firms would need to cope with. Second, M\&A decisions are shown to be firmly and significantly affected by the financial performance of GCC firms as measured by their average ROE. This result complies with the findings of Palade (2016) and supports Hypothesis 4. This implies that GCC firms expand to hazardous MENA environments only when they are assured of their capacity to achieve profitability, which is in accordance with evolutionary theories of internationalization stating that gaining stable position in the home country is a prerequisite for cross-border investment. Our results show that there is no significant impact of leverage, as measured by $\mathrm{D} / \mathrm{E}$, on the probability of conducting an M\&A transaction with the MENA region. Previous empirical studies have shown a positive and significant effect of leverage on outward FDI by using different measures than ours. Hypothesis 5 states that outward FDI is positively affected by state ownership. Our empirical results refute this hypothesis by indicating an adverse and significant effect of the state ownership on the probability of an M\&A transaction by a GCC-firm within the MENA region. Our attempt 
to explain this result is based on the fact that the vast majority of outward FDI by GCC firms targets nonMENA countries (Sekkat, 2014). It also seems that higher public stakes imply more risk aversion towards investments in risky countries in the MENA region. A previous study demonstrated indeed a robust negative relationship between state ownership and corporate risk-taking (Boubakri, Cosset \& Saffar, 2013).

Table 2

Logistic regression results

\begin{tabular}{|l|c|c|}
\hline \multicolumn{1}{|c|}{ Estimation results } & & \\
\hline \multirow{2}{*}{ Total Assets } & Model (1) & Model (2) \\
\cline { 2 - 3 } & $0.241^{* * *}$ & $1.273^{* * *}$ \\
\cline { 2 - 3 } & $(0.0433)$ & $(0.0551)$ \\
\hline \multirow{2}{*}{ Levformance } & $2.409^{* * *}$ & $11.12^{* * *}$ \\
\cline { 2 - 3 } & $(0.701)$ & $(7.798)$ \\
\hline \multirow{2}{*}{ Ownership } & -0.00624 & 0.994 \\
\cline { 2 - 3 } & $(0.0606)$ & $(0.0602)$ \\
\hline \multirow{2}{*}{ Active Years } & $-1.082^{*}$ & $0.339 *$ \\
& $(0.649)$ & $(0.220)$ \\
\hline \multirow{2}{*}{ Constant } & -0.00737 & 0.993 \\
\cline { 2 - 3 } & $(0.00739)$ & $(0.00734)$ \\
\hline Observations & $-6.217 * * *$ & $0.00200^{* * *}$ \\
\hline Pseudo R-squared & $(0.900)$ & $(0.00180)$ \\
\hline Log-Likelihood & 613 & 613 \\
\hline Degrees of freedom & 0.0869 & \\
\hline Chi-squared & -296.2 & \\
\hline
\end{tabular}

Standard errors in parentheses: ${ }^{* *} \mathrm{p}<0.01, * * \mathrm{p}<0.05, * \mathrm{p}<0.1$

Therefore, GCC governments consider these investments as strategic and devote a significant proportion of their resources to achieve them. As a result, companies that are not partly owned by their governments are more likely to expand and invest within the MENA region. Finally, our empirical results show no significant effect of the number of active years on the probability of undertaking an outward FDI within the MENA region. Therefore, our empirical evidence does not validate Hypothesis 1. We explain this result by the fact that most GCC firms employ many qualified workers from the MENA region. Therefore, the knowledge about local markets, cultures, and practices would be no longer an issue for newlyfounded GCC firms. Besides, the emergence of born global firms that internationalize soon after their inception demonstrated that age is not a determinant factor in explaining international growth(Bell, McNaughton, \& Young, 2001; Oviatt \& McDougall, 1997).

\section{CONCLUSIONS}

In this manuscript, the objective was to untangle the characteristics of local investors expanding inside the MENA region. Five firm-level dimensions were advocated, namely age, size, performance, leverage, and state-ownership. The central premise rests on the preeminence of firm-level variables in explaining GCCFDI outflows into MENA economies, as previous research points out to the atypical reaction of local investors to dissuasive institutional and macroeconomic indicators in those host countries. FDI conducted by GCC companies in other MENA countries are essential and can be spotted in different sectors, notably 
food industry (restaurants, supermarkets, dairy products, etc.), banking, construction, real estate, tourism, and telecommunications.

The contributions are numerous indeed. First, the paper proposes a framework that could inform authorities in MENA countries on the appropriate policies that should be undertaken to meet the expectations of a particular group of investors. Also, no research has uncovered the identity and the intentions of local investors in that region. The inclusion of state ownership variable has shown that GCC countries are not using FDI as a strategy to capitalize on their economic power in the region.

As empirical evidence supports the assumptions developed in this paper, it can contribute to illuminating an underexplored area of research. This work paves the way for other empirical studies that could include locational variables in host countries and test their moderating effect on the influence of the investing firm characteristics on FDI decision.

As for limitations, this research did not account for the effect of cultural proximity, stated as a prominent firm characteristic affecting GCC firms' decision to conduct cross-border M\&As (Dowling \& Vanwalleghem, 2018). In particular, GCC investors usually strive to abide by the tenets of the Islamic business doctrine when investing in other countries. Proper understanding and application of Islamic principles facilitate business and commerce in Muslim countries. Principles enumerated are based on compassion, fairness, partnerships, family connections and prohibition of interest and speculation (Lagace, 2002). Therefore, demonstrating the potential effect stemming from cultural/religious proximity could also justify the preference of GCC investors to do business in the MENA region.

\section{REFERENCES}

Abidi, O., Dzenopoljac, V., \& Janosevic, S. (2017). A reflective analysis of firm-level determinants of binary investments between MENA countries, Ekonomika preduréáa, 65(7-8), 427-435. doi: 10.5937/EKOPRE1708427A

Al-Jaifi, H. A. A., Abdullah, N. A. H., \& Regupathi, A. (2016). Risks and foreign direct investment inflows: Evidence from Yemen. Jurnal Pengurusan, 46, 89-97. Retrieved from http://ejournal.ukm.my/pengurusan/article/view/8932

Aysan, A., Pang, G., \& Veganzones-Varoudakis, M.-A. (2009). Uncertainty, economic reforms and private investment in the Middle East and North Africa. Applied Economics, 41(11), 1379-1395. https://doi.org/http://dx.doi.org/10.1080/00036840601019315

Bell, J., McNaughton, R., \& Young, S. (2001). "Born-again global" firms: An extension to the "born global" phenomenon. Journal of International Management, 7(3), 173-189. https://doi.org/10.1016/S1075-4253(01)00043$\underline{6}$

Bevan, A. A., \& Estrin, S. (2004). The determinants of foreign direct investment into European transition economies. Journal of Comparative Economics, 32(4), 775-787. https://doi.org/10.1016/i.jce.2004.08.006

Boubakri, N., Cosset, J. C., \& Saffar, W. (2013). The role of state and foreign owners in corporate risk-taking: Evidence from privatization. Journal of Financial Economics, 108(3), 641-658. Retrieved from https://www.erim.eur.nl/fileadmin/erim content/documents/Risk Taking in NPFs-April 2012.pdf

Cammett, M. (1999). Defensive integration and late developers: The Gulf Cooperation Council and the Arab Maghreb Union. Global Governance, 5(3), 379-402. Retrieved from http://www.jstor.org/stable/27800238

Chiemeke, C. C. (2012). Globalization in the Middle East and North Africa: The role of multinational enterprises and the evolving challenges for economic development. Journal of Business and Behavioral Sciences, 24(3), 161-183. https://doi.org/10.1596/0-8213-4989-9

De Beule, F., \& Duanmu, J. L. (2012). Locational determinants of internationalization: A firm-level analysis of Chinese and Indian acquisitions. European Management Journal, 30(3), 264-277. https://doi.org/10.1016/j.emj.2012.03.006

Dowling, M., \& Vanwalleghem, D. (2018). Gulf Cooperation Council cross-border M\&A: Institutional determinants of target nation selection. Research in International Business and Finance. Retrieved from https://papers.ssrn.com/sol3/papers.cfm?abstract id=3201292 
Duanmu, J.-L. (2014). State-owned MNCs and host country expropriation risk: The role of home state soft power and economic gunboat diplomacy. Journal of International Business Studies, 45(8), 1044-1060. https://doi.org/10.1057/jibs.2014.16

Dunning, J. H. (1977). Trade, Location of Economic Activity and the MNE: A Search for an Eclectic Approach. In The International Allocation of Economic Activity: Proceedings of Nobel Symposium Held at Stockholm (pp. 395-418). https://doi.org/10.1007/978-1-349-03196-2 38

Dunning, J. H. (2000). The eclectic paradigm as an envelope for economic and business theories of MNE activity. International Business Review, 9(2), 163-190. https://doi.org/10.1016/S0969-5931(99)00035-9

Dzenopoljac, V., Yaacoub, C., Elkanj, N., and Bontis, N. (2017) "Impact of intellectual capital on corporate performance: evidence from the Arab region", Journal of Intellectual Capital, 18(4), 884-903. https://doi.org/10.1108/JIC-01-2017-0014

Dzenopoljac V, Alasadi R, Zaim H, and Bontis N. (2018). Impact of knowledge management processes on business performance: Evidence from Kuwait. Knowledge and Process Management, 25, 77-87. https://doi.org/10.1002/kpm.1562

Helmy, H. E. (2013). The impact of corruption on FDI: Is MENA an exception? International Review of Applied Economics, 27(4), 491-514. https://doi.org/10.1080/02692171.2012.752445

Hymer, S. H. (1960). The International Operations of National Firms: A Study of Direct Foreign Investment. MITPress: Cambridge, MA. https://doi.org/10.1007/s13398-014-0173-7.2

Hyun, H. J., \& Hur, J. (2013). Who goes where and how? Firm and country characteristics in the choice of FDI type and location. Asian-Pacific Economic Literature, 27(2), 144-158. https://doi.org/10.1111/apel.12029

Jadhav, P. (2012). Determinants of foreign direct investment in BRICS economies: Analysis of economic, institutional and political factor. Procedia - Social and Behavioral Sciences, 37, 5-14. https://doi.org/10.1016/j.sbspro.2012.03.270

Johanson, J., \& Vahlne, J.-E. (1977). The internationalization process of the firm-a model of knowledge development and increasing foreign market Commitments. Journal of International Business Studies, 8(1), $23-32$. https://doi.org/10.1057/palgrave.jibs.8490676

Kanady, S. (2017). Arab countries’ FDI outflows jump to $\$ 28.4$ bn. Retrieved November 29, 2017, from https://www.thepeninsulaqatar.com/article/31/01/2017/Arab-countries-FDI-outflows-jump-to-\$28.4bn

Kotha, R., Zheng, Y., \& George, G. (2011). Entry into new niches: The effects of firm age and the expansion of technological capabilities on innovative output and impact. Strategic Management Journal, 32(9), 1011-1024. https://doi.org/10.1002/smj.915

Kotha, S., Rindova, V. V. P., \& Rothaermel, F. T. F. (2001). Assets and actions: Firm-specific factors in the internationalization of U.S. internet firms. Journal of International Business Studies, 32(4), 769-791. https://doi.org/10.1057/palgrave.jibs.8490994

Lagace, M. (2002). How to do business in Islamic countries. Working Knowledge: Business Research for Business Leaders. Harvard Business School. Retrieved August 27, 2018, from https://hbswk.hbs.edu/item/how-to-dobusiness-in-islamic-countries

Lu, J., Liu, X., Wright, M., \& Filatotchev, I. (2014). International experience and FDI location choices of Chinese firms: The moderating effects of home country government support and host country institutions. Journal of International Business Studies, 45(4), 428-449. https://doi.org/10.1057/jibs.2013.68

Mehta, S. (2016). Technology intensity and outward foreign direct investment from the Indian manufacturing sector: A firm-level analysis. International Journal of Technology Management \& Sustainable Development, 15(1), 37-59. https://doi.org/10.1386/tmsd.15.1.37 1

Mohamed, S. E., \& Sidiropoulos, G. (2010). Another Look at the Determinants of Foreign Direct Investment in MENA Countries: An Empirical Investigation. Journal of Economic Development, 35(2), 75-95.

Moosa, I. A. (2009). The determinants of foreign direct investment in MENA countries: An extreme bounds analysis. Applied Economics Letters, 16(15), 1559-1563. https://doi.org/10.1080/13504850701578819

Morck, R., Shaver, J. M., Yeung, B., \& Acs, Z. J. (1997). The internationalization of small and medium-sized enterprises : a policy perspective. Small Business Economics, 9, 7-20. https://doi.org/10.1023/A:1007991428526

Nunnenkamp, P. (2002). Determinants of FDI in developing countries: has globalization changed the rules of the game? Kiel Institute for World Economics Working Paper, 1122(November), 1-34. https://doi.org/10.1007/s10273-011-1262-2 
Oviatt, B. M., \& McDougall, P. P. (1997). Challenges for Internationalization Process Theory: The Case of International New Ventures. Management International Review, 37, 85-99. https://doi.org/10.2307/40228434

Palade, D. P. (2016). Firm characteristics and their effects on foreign direct investment: evidence from Romania, Republic of Moldova, and Republic of Turkey. Acta Universitatis Danubius. Oeconomica, 12(6), 119-133.

Pradhan, J. P. (2004). The determinants of outward foreign direct investment: A firm-level analysis of Indian manufacturing. Oxford Development Studies, 32(4), 619-639. https://doi.org/10.1080/1360081042000293371

Pugel, T. A. (1981). The Determinants of foreign direct investment: an analysis of US manufacturing industries. Managerial \& Decision Economics, 2(4), 220-228. Retrieved from http:/ / ezproxy.library.capella.edu/login?url=http:// search.ebscohost.com/login.aspx?direct=true\&db=bth\& $\underline{\text { AN }=6244649 \& \text { site }=\text { ehost-live } \& \text { scope }=\text { site }}$

Rogmans, T., \& Ebbers, H. (2013). The determinants of foreign direct investment in the Middle East North Africa region. International Journal of Emerging Markets, 8(3), 240-257. https://doi.org/10.1108/17468801311330310

Romagnoli, A., \& Mengoni, L. (2009). The challenge of economic integration in the MENA region: From GAFTA and EU-MFTA to small scale Arab Unions. Economic Change and Restructuring, 42(1-2), 69-83. https://doi.org/10.1007/s10644-008-9058-0

Salem, M., \& Baum, A. (2016). Determinants of foreign direct real estate investment in selected MENA countries. Journal of Property Investment \& Finance, 34(2), 116-142. https://doi.org/10.1108/JPIF-06-2015-0042

Sekkat, K. (2014). Is there anything special with Intra-Arab foreign direct investment? Journal of Economic Integration, 29(1), 139-164. https://doi.org/10.11130/jei.2014.29.1.139

Thomas, R., \& Narayanan, K. (2017). Determinants of outward foreign direct investment: a study of Indian manufacturing firms. Transnational Corporations, 24(1), 9-26.

Todo, Y. (2011). Quantitative evaluation of the determinants of export and FDI: firm-level evidence from Japan. World Economy, 34(3), 355-381. https://doi.org/10.1111/j.1467-9701.2011.01331.x

Toone, J. (2012). Mirage in the Gulf?: Examining the upsurge in FDI in the Gcc and its legal and economic implications for the MENA region. Emory International Law Review, 26(2), 677-731.

United Nations Conference on Trade and Development (2018). World Investment Report: Investment and New Industrial Policies. UNCTAD/WIR/2018. ISBN: 978-92-1-112926-7

Van Wyk, J., \& Lal, A. K. (2010). FDI location drivers and risks in MENA. Journal of International Business Research, 9(2), 99-117.

Wang, C., Hong, J., Kafouros, M., \& Boateng, A. (2012). What drives outward FDI of Chinese firms? Testing the explanatory power of three theoretical frameworks. International Business Review, 21(3), 425-438. https://doi.org/10.1016/j.ibusrev.2011.05.004

Wang, P., Alba, J. D., \& Park, D. (2013). Determinants of different modes of FDI: firm-level evidence from Japanese FDI into the US. Open Economies Review, 24(3), 425-446. https://doi.org/10.1007/s11079-012-9244-6

Withers, M. C., Drnevich, P. L., \& Marino, L. (2011). Doing more with less: the disordinal implications of firm age for leveraging capabilities for innovation activity. Journal of Small Business Management, 49(4), 515-536. https://doi.org/10.1111/j.1540-627X.2011.00334.x

Yean, T. S., Nee, T. Y., \& Yi, A. K. J. (2015). Outward foreign direct investment from Malaysia. Journal of Southeast Asian Economies, 32(3), 358-374. https://doi.org/10.1355/ae32-3d 


\section{APPENDIX}

Table A1

Number of M\&A transactions per GCC country during the period 2008-2016

\begin{tabular}{|lc|c|c|c|c|c|c|}
\hline \multicolumn{7}{|c|}{ Number of M\&A transactions per country during the period 2008-2016 } \\
\hline & Bahrain & Kuwait & Oman & Qatar & Saudi Arabia & $\begin{array}{c}\text { United Arab } \\
\text { Emirates }\end{array}$ \\
\hline $\begin{array}{l}\text { outward M\&As per } \\
\text { country }\end{array}$ & 15 & 41 & 11 & 11 & 27 & 31 \\
\hline $\begin{array}{l}\text { Total number of } \\
\text { observed firms }\end{array}$ & 37 & 177 & 112 & 46 & 135 & 106 \\
\hline
\end{tabular}

Table A2

Goodness-of-Fit

\begin{tabular}{|c|c|}
\hline \multicolumn{2}{|c|}{ Log-likelihood } \\
\hline Model & -296.229 \\
\hline Intercept-only & -324.431 \\
\hline \multicolumn{2}{|c|}{ Chi-square } \\
\hline Deviance $(\mathrm{df}=607)$ & 592.459 \\
\hline $\mathrm{LR}(\mathrm{df}=5)$ & 56.404 \\
\hline $\mathrm{p}$-value & 0 \\
\hline \multicolumn{2}{|c|}{ R-square } \\
\hline McFadden & 0.087 \\
\hline McFadden (adjusted) & 0.068 \\
\hline McKelvey \& Zavoina & 0.399 \\
\hline Cox-Snell/ML & 0.088 \\
\hline Cragg-Uhler/Nagelkerke & 0.135 \\
\hline Efron & 0.08 \\
\hline Tjur's D & 0.085 \\
\hline Count & 0.772 \\
\hline Count (adjusted) & -0.029 \\
\hline \multicolumn{2}{|l|}{ Information Criteria } \\
\hline AIC & 604.459 \\
\hline AIC divided by $\mathrm{N}$ & 0.986 \\
\hline $\mathrm{BIC}(\mathrm{df}=6)$ & 630.969 \\
\hline \multicolumn{2}{|l|}{ Variance of } \\
\hline e & 3.29 \\
\hline$y$-star & 5.479 \\
\hline
\end{tabular}

